\title{
Centre of Sustainable Development and Energy Saving 'Miękinia'
}

\author{
Wojciech Górecki, Jarosław Kotyza, Elżbieta Hałaj, Wojciech Luboń, \\ Grzegorz Pełka
}

\section{INTRODUCTION}

The educational and scientific activity of the Faculty of Geology, Geophysics and Environment Protection, AGH University of Science and Technology (AGH UST), Kraków, Poland, is closely related to the subject-matter of renewable energy sources (RES). The specialty "renewable energy sources" has existed and research work in this field has been conducted at the faculty for several years. It created the need for the establishment of educational and research infrastructure to enable practical courses and laboratory studies, which would enrich the educational offer of the University and improve the quality of the research work. Courses at laboratory stands complement theoretical knowledge and the previous lack of sites for the practical training of students made it necessary to organize the training outside of the University, which generated additional costs and reduced the potential for detailed analysis of installations based on RES. The creation of the AGH UST Centre of Sustainable Development and Energy Saving in Miękinia provides new possibilities for students and scientific workers of the University.

The AGH UST Educational and Research Laboratory of Renewable Energy Sources and Energy Saving in Miękinia-Krzeszowice commune, which has been constructed on the basis of an existing building, is the first stage of the wider project called AGH UST Centre of Sustainable Development and Energy Saving in Miękinia. The building has been modernized to place laboratory stands for providing courses and doing laboratory work. Moreover, the reconstruction aim was to improve the energy efficiency of the building. Construction of the Laboratory was co-financed by the European Regional Development Fund of the European Union under the Małopolska Regional Operational Programme 2007-2013.

\section{AIMS OF THE PROJECT}

A direct aim of the project is to improve the teaching quality as a result of possession of a modern research and educational laboratory, which enables practical training for more students than was previously possible. Growing interest in using the renewable energy sources (RES) is reflected upon in the interest in such a discipline of studies and more and more people are declaring an intention to study RES. This is a modern discipline, opened at AGH UST in 2003 as the first in Poland. Since that time, the number of students choosing this specialty has been steadily growing. Students use the modernized educational infrastructure and scientific-research equipment located within the building and its surroundings. The realization of the project and the creation of greater educational possibilities have resulted in an increasing number of students interested in acquiring knowledge in this discipline, improving the educational quality by adding a growing number of practical courses, and conducting the research study for the engineer's thesis, master's thesis and doctoral dissertations, which significantly facilitate student research activity and improve the quality of the theses.

The laboratory represents a site of practical courses for students from different faculties of AGH UST and other universities and schools in Małopolska, the syllabuses of which concern problems of environment protection. The activity of the laboratory has allowed us to increase 
the number of exchanges of students from AGH UST and other universities from all over Europe. The practical use of up-to-date technologies in RES results in the improvement of conditions for professional study, allowing professional qualifications to be improved by supplying students and teachers with modern technical and didactic equipment.

Apart from the activity directed to students needs, the laboratory plays an informative and consultative role in the fields of renewable energy sources and energy conservation for people interested in this subject. Open days are organized on which students of secondary schools are able to familiarize themselves with the subject in the laboratory. In agreement with the authorities of the Krzeszowice commune, meetings with residents are organized in order to arouse their interest in the problems of energy conservation. Weekend courses for scientific associations involved in RES at different universities are also planned.

The main aim of the Centre of Sustainable Development and Energy Saving in Miękinia is scientific cooperation with micro and small businesses in the field of RES.

\section{DESCRIPTION OF THE CRUCIAL LABORATORY EQUIPMENT}

The AGH UST Educational and Research Laboratory of Renewable Energy Sources and Energy Saving in Miękinia is located in an old quarry. It is housed in the former administrative building of the porphyry mine in Miękinia. Within the project, the building was completely redesigned, achieving energy-efficient building characteristics and meeting the needs for the RES laboratory. Realization of the project will represent the first element of the revitalization planned by the Krzeszowice commune and the AGH University of Science and Technology in Kraków.

Education and research activities in the field of geothermal energy in the laboratory are based on heat pumps. The laboratory is heated by four heat pumps with ground sources (Fig. 1). Heat pumps work in three different heating systems. The first one has three borehole heat exchangers (each of them at a depth of $83 \mathrm{~m}$ ) and warm or cool air is distributed through the building using ventilation ducts. The second heat pump has three borehole heat exchangers (each of them at a depth of $87 \mathrm{~m}$ ) and warm or cool air distributed by under floor heating. The third and fourth heat pumps work together and they are used to produce high temperature heat (for a heat pump, a high temperature is from $50^{\circ} \mathrm{C}$ to $55^{\circ} \mathrm{C}$ ) for domestic hot water and to distribute heat to the building via radiators. The third heat pump has three borehole heat exchangers (each of them at a depth of $100 \mathrm{~m}$ ) as a source and the fourth has the horizontal ground source (600 $\mathrm{m}^{2}$ of area). The main aim of the heat pumps installed in the laboratory is the heating and cooling of the building and the production of domestic hot water. Chill is supplied to the building in a passive way, without using a compressor. The installation is measured with temperature sensors, heat meters and electric meters. Temperature sensors give data about brine and boiler water. Heat meters and electric meters provide information about the quantity of heat production and electric consumption of the compressor and other devices like the circulation pump, controller etc. All data is saved on a server and accessed by a computer program. The software affords opportunities for viewing present and archival parameters of the installation as graphs of temperature, energy consumption, energy produced etc., or to calculate the efficiency of the heat pump in any period. Using the software it is possible to control the heat pumps from anywhere in the world (Fig. 2). Archived data are used to create theses by students and for experiments by researchers from the University.

Except for the four heat pumps which heat the building, there are two heat pumps in the laboratory for didactic purposes. The first of them is an air-water type heat pump (Fig. 3). The whole kit consists of three modules: an energy source module, a heat pump module and a heating system module. Energy source and heating system modules have the ability to set the temperature parameters, which allows the comparison of Seasonal Performance Factor depending on different temperatures of the energy source and heating system. The second didactic heat pump is a small water-water device of the direct evaporation type (Fig. 4). 


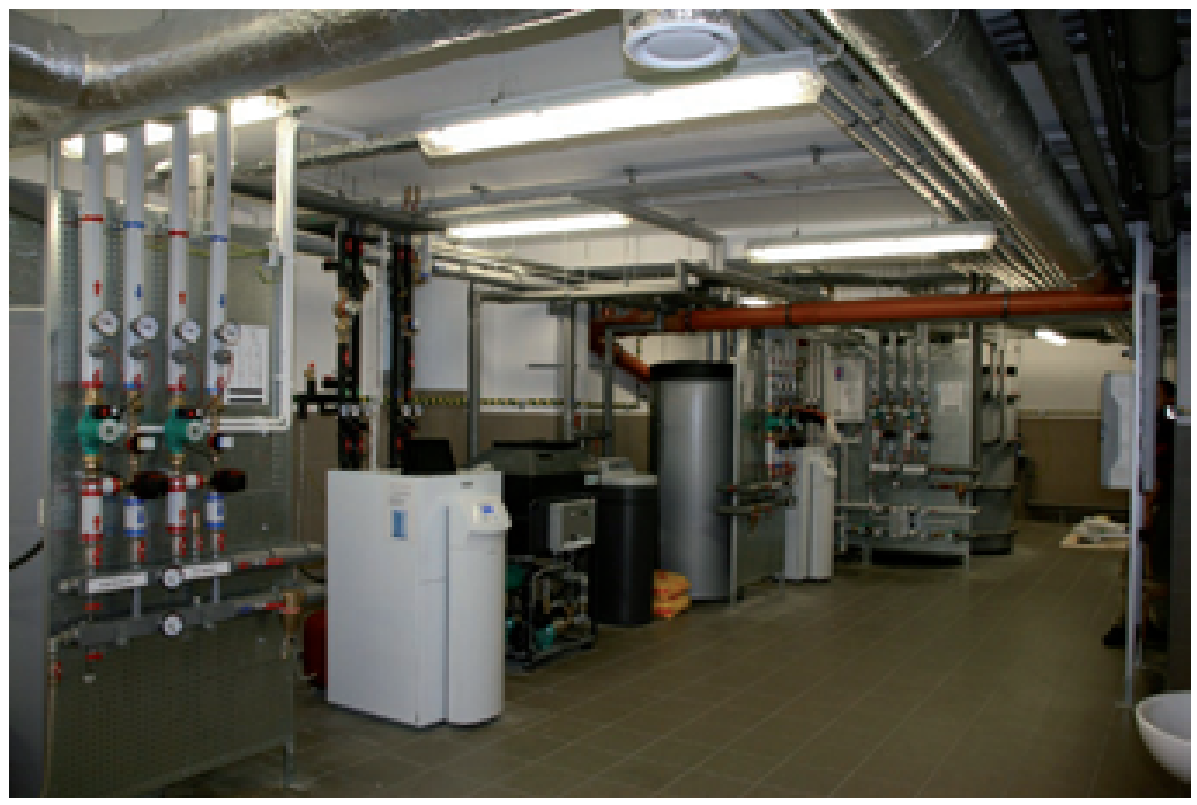

Fig. 1. View of the boiler room with the installed heat pumps

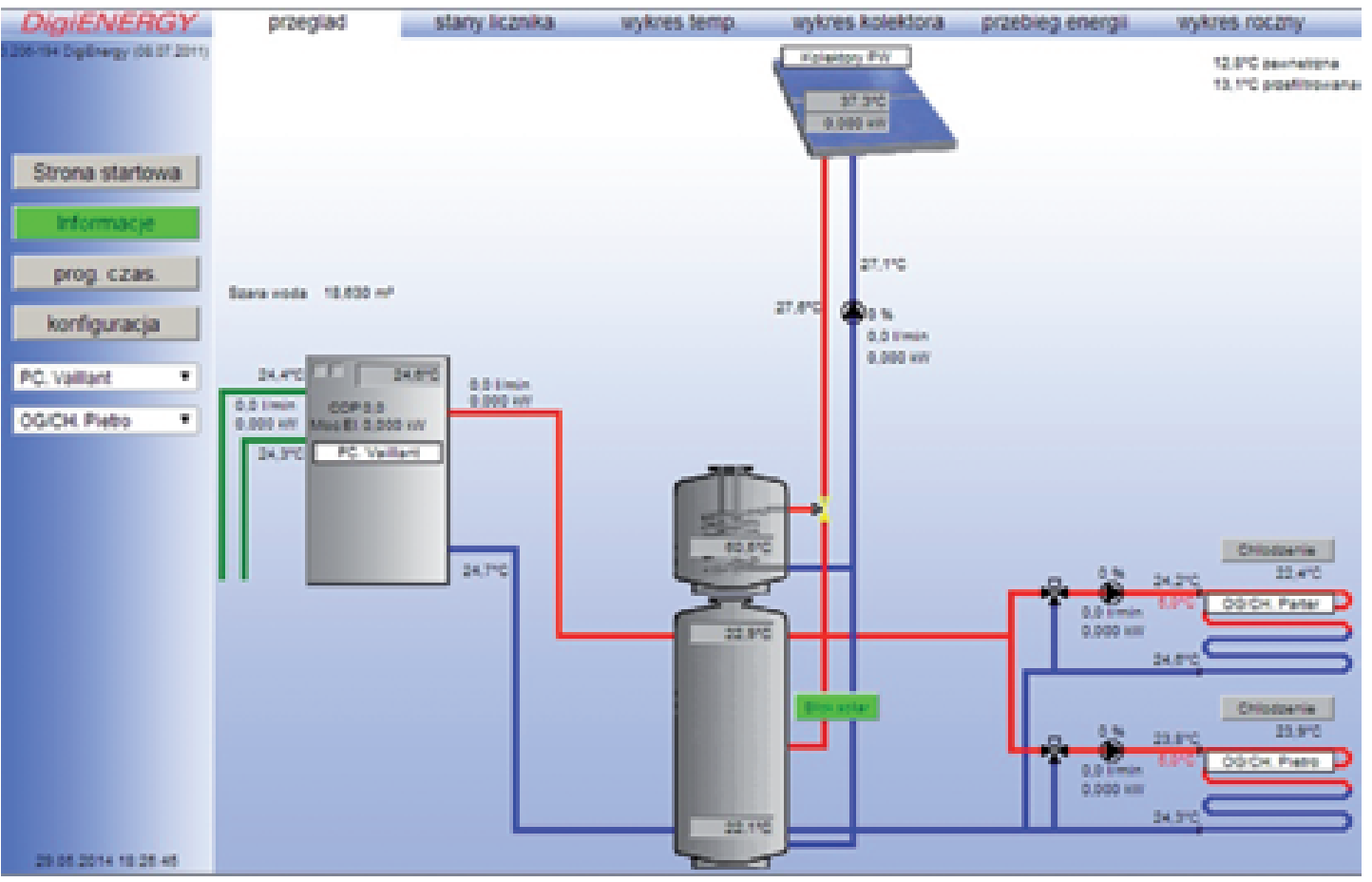

Fig. 2. The system of heat pump monitoring in the laboratory, controlling the work parameters and archiving data

This heat pump also has temperature and pressure sensors and an electricity meter. It is possible to show how the four-way valve works and the ability to cool the building in an active way by means of a heat pump using the compressor.
The staff of the Laboratory has constructed a self-made Thermal Response Test Equipment. It has been constructed for testing BHE using heating with the constant power method. The power range of the device is from $2 \mathrm{~kW}$ to $12 \mathrm{~kW}$. It can test borehole heat exchangers atdepths from $30 \mathrm{~m}$ to $250 \mathrm{~m}$. 


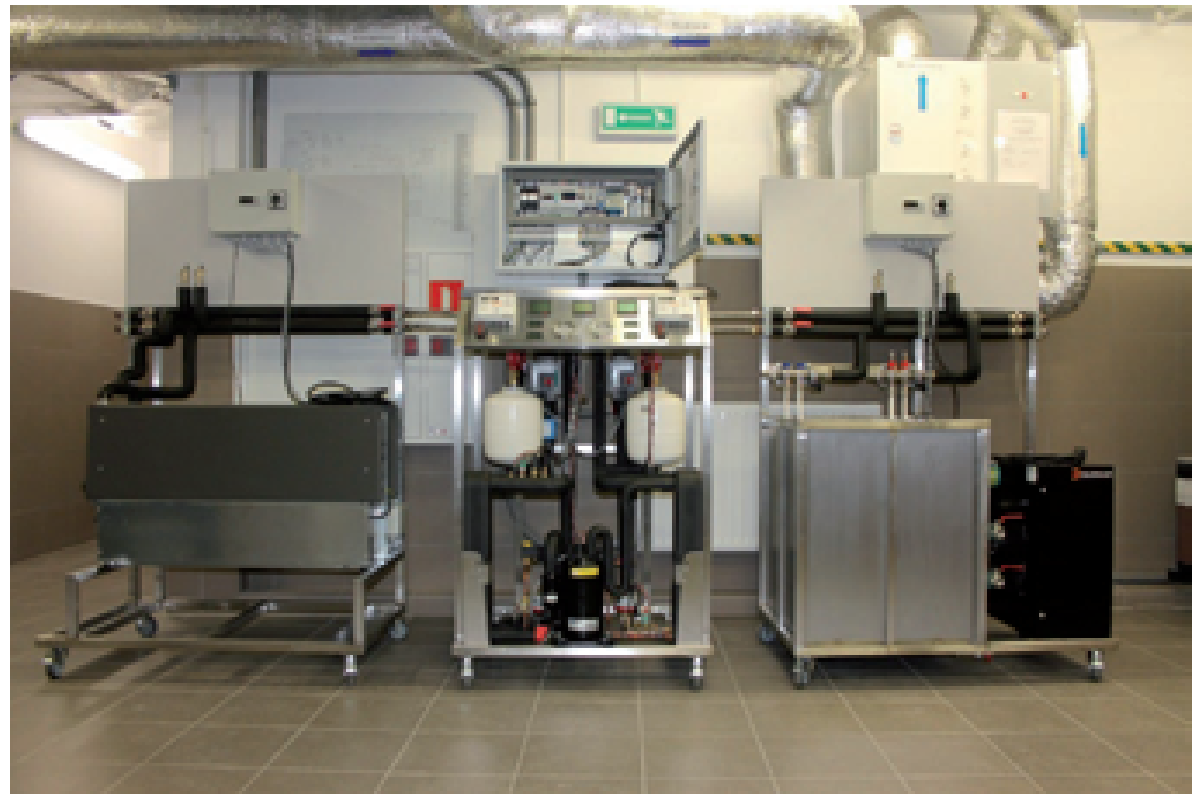

Fig. 3. Didactic air-water type heat pump. Energy source, heat pump and heating system modules

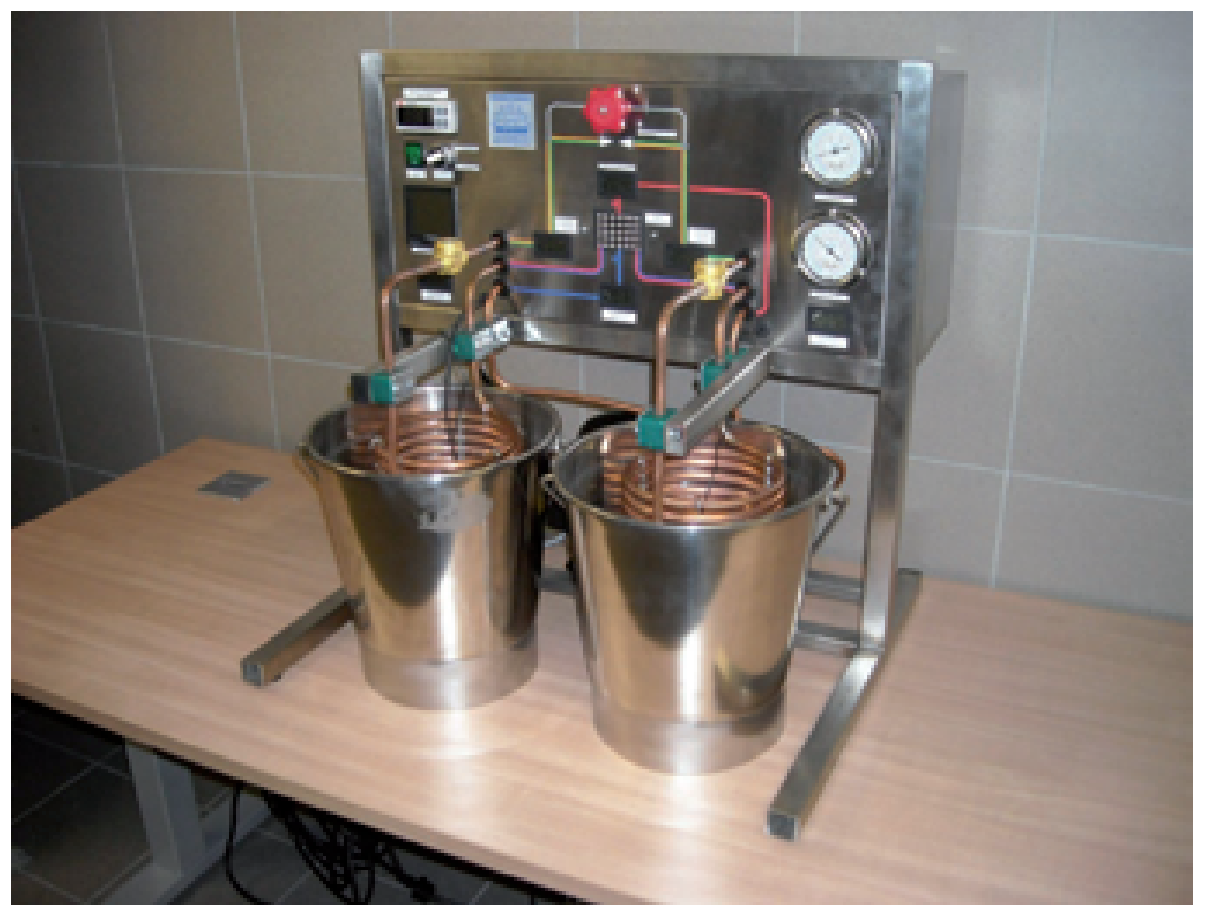

Fig. 4. Didactic heat pump, water-water of the direct evaporation type

The results of the test give the information about:

- effective thermal conductivity of the ground,

- undisturbed ground temperature,

- average thermal resistance of the borehole heat exchanger.
The Laboratory also has equipment for air-water heat pump testing. A climatic chamber is used for the examination of the efficiency of air heat pumps. Research in the chamber is carried out in accordance with the PN-EN 16147 standard. It is pre-certificate research of new constructions and 
the results are used to aid the technical innovation corrections of newly constructed equipment.

In the field of solar thermal energy there are three didactic and testing systems. The first is connected with the heat pump heating system and consists of three fields of solar collectors which support the supply of domestic hot water for the Laboratory. One of them is a flat solar collector field and the other are evacuated tube solar collectors using heat pipe technology.

In the field of photovoltaics, there are a few research and didactic installations which have been developed in the Laboratory:

- suitcase training stand,

- on and off-grid training installation,

- off-grid hybrid wind and PV installation,

- research installation for field testing of different types of PV modules (Fig. 5),

- research installation built on a tracking system for field testing PV module with an anti-reflective coating.

The following parameters are measured and logged:

- solar irradiance,

- air temperature and PV modules temperature,

- power, current energy on DC and AC side.

Besides those described above, there are many other didactic stands, i.e. a biogas production tester, a pellet boiler room, a moisture analyser, a muffle furnace, a calorimeter, a PV testing meter, a wind station.

\section{RESEARCH AREA}

The research activity of the Centre of Sustainable Development and Energy Saving in Miekinia focuses on the environmental aspects of renewable energy yield. One of the research fields is the testing of the seasonal effectiveness of shallow geothermal ground sources of heat pumps on the dependence of the specific power extracted. The tests are conducted using ground source heat pump equipment in the normal and extreme exploitation of borehole heat exchangers. In the Laboratory a borehole heat exchanger of the double U-pipe type is monitored. There is the possibility of conducting a thermal response test for testing borehole heat exchangers. In the Laboratory there is also a stand for testing geothermal heat pumps with up to $25 \mathrm{~kW}$ heating power during the season. The main aim of the test is long term testing and seasonal efficiency calculation.

In the field of air source heat pumps (ASHP), the laboratory has a chamber with adjustable temperatures and humidity of air for testing air source heat pumps. The Laboratory conducts pre-certification tests for domestic hot water heat pumps. In the field of air heat pumps, research on improving the efficiency of the heat pumps is conducted.

In the field of photovoltaics, the main research activity in the Laboratory focuses on the field tests of various PV panels and the influence of environmental parameters on PV productivity. The research installation is built from silicon panels and thin-film panels with a nominal power about $250 \mathrm{~W}$. PV panels are installed at an angle of 33 degrees on the stationary solar panel system on the ground.

In the measuring station on the DC side (before the micro inverter) multifunction meters: Nemo D4DC are used for each PV panel to obtain data such as the amount of energy production, actual power, voltage and current of PV panel. To convert energy from direct current to alternating

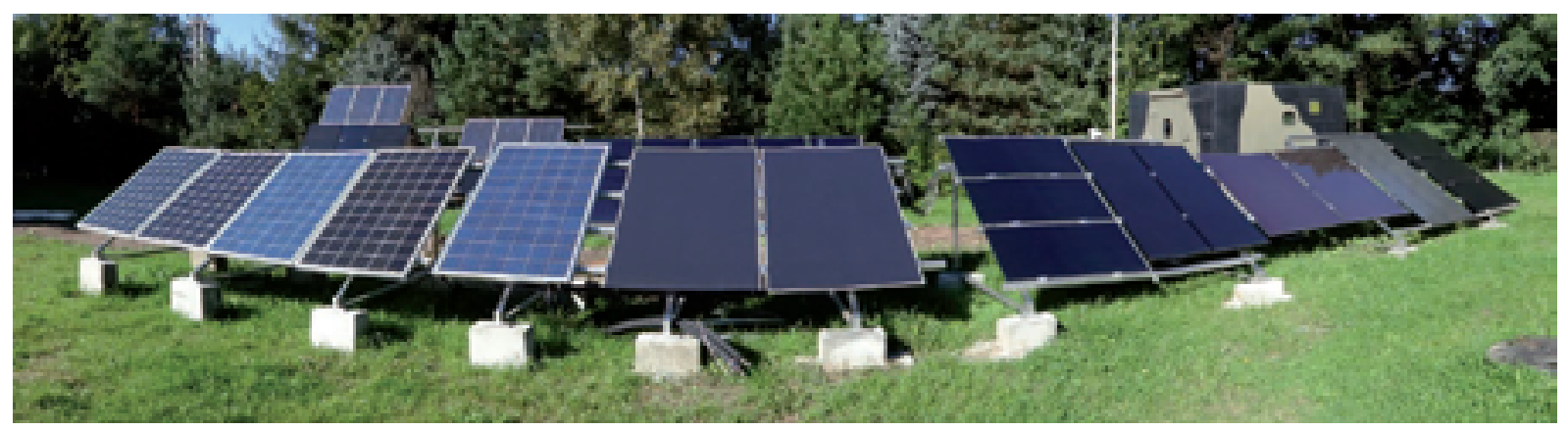

Fig. 5. Research installation for the field testing of different types of PV modules 
current, micro inverters are used. Each PV panel supports one micro inverter. On the alternating current side an electrical network analyzers: F\&F LE 01MP are used for each PV panel to obtain data such as the amount of energy production and actual power of the PV panel.

This installation provides information about:

- the influence of solar radiation on power conversion efficiency of $\mathrm{PV}$ panels,

- the energy production recalculated on energy from kilowatts peak $(\mathrm{kWp})$ and energy generated from the square meter of module,

- temperature power coefficient,

- efficiency of inverters.

Data from this system allows us to research the impact of environmental conditions on the production of electricity from different photovoltaic modules. Research is also being made into the impact of washing modules for their work.

The basic parameters of windiness like wind speed at two levels, direction of wind, humidity and air temperature are also measured in the Laboratory. These provide material for research in the area of prediction for wind energy production in the small wind turbine located in the Laboratory.

\section{EDUCATIONAL AND TEACHING OFFER}

The main aim of the AGH UST Educational and Research Laboratory of Renewable Energy Sources and Energy Saving in Miękinia is didactic and training. The educational areas which are in the Laboratory are the main place for practical lessons for students in the field of Ecological Energy Sources, Environmental Engineering and Environmental Protection studies. The following modules are taught: Renewable Energy Sources, Heat Pumps, Bioenergy, Solar Thermal Energy, Photovoltaics and Wind Energy. The Centre also has a computer laboratory with software for projects and designing in the field of renewable energy. The Laboratory also has an offer for students from other Faculties from AGH UST and other universities. Other student groups come to the Laboratory to deepen their knowledge about the RES facilities.

There is also cooperation with the RES Technical School from Krzeszowice and students from the school have practice lectures in the laboratory.

The laboratory offers cyclic branch meetings called "Energy Think Tank" for the local authorities and community, businessmen and scientists. This is a platform for exchanging experience, creating a new quality for renewable energy source installations.

The mobile RES exhibition is a great tool for the popularization of RES ideas (Fig. 6).

\section{COOPERATION}

Despite the fact that the Centre in Miękinia has only existed for five years, it has extensive experience in conducting research and the popularization of renewable energy sources.

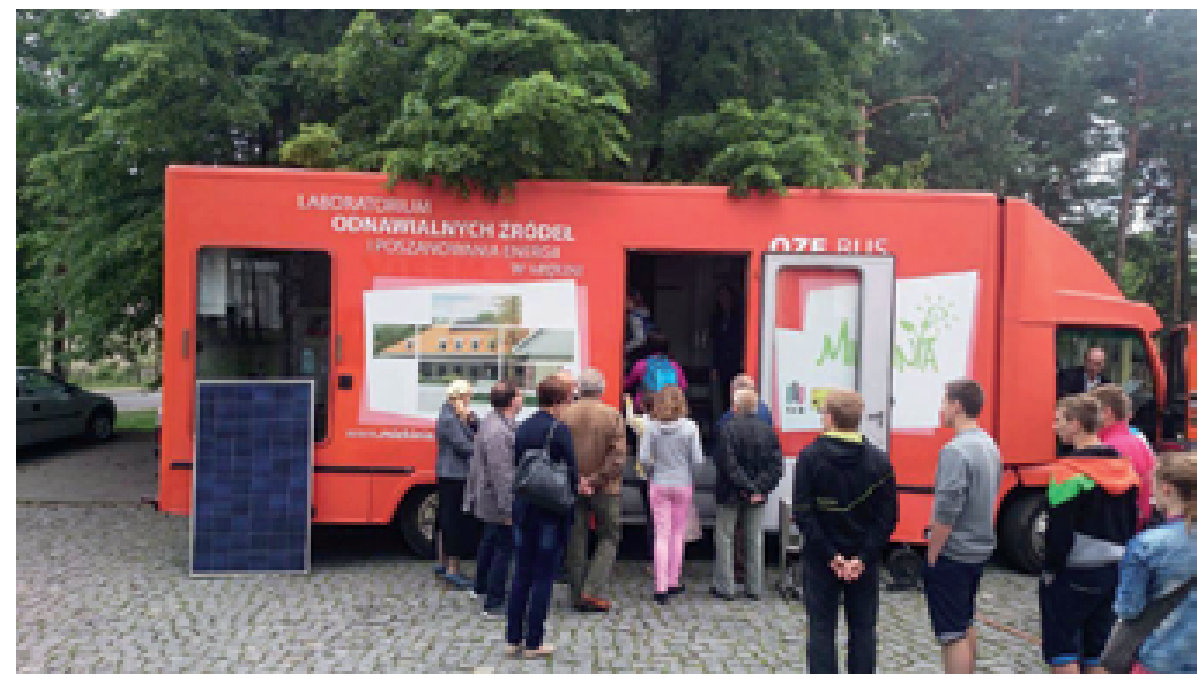

Fig. 6. Mobile RES exhibition 
The Centre is ready to carry out the following activities:

- field testing ground source heat pumps (GSHP) up to $30 \mathrm{~kW}$ heating capacity,

- pre-certification testing of domestic hot water heat pumps (GHWHP),

- testing air source heat pumps (ASHP) up to $12 \mathrm{~kW}$ power capacity,

- the Thermal Response Testing of the ground source of heat for heat pumps,

- field testing of PV-panels,

- improving the existing installations based on heat pumps and solar collectors,

- testing new products like heat pumps, solar collectors, PV panels and biomass boilers,

- R\&D activities in the RES field,

- audit of PV installation,
- consulting services for local government, companies or users,

- didactic offer for installers, designers and users,

- mobile RES exhibition for the popularization of RES in the country.

The Center cooperates with: Małopolska Region, Faculty of Informatics, Electronics, and Telecommunication AGH UST, Galmet sp. z o.o., Viessmann sp. z o.o., Kołton s.c., Frapol sp. z o.o., PGNiG SA, Exalo SA, Geofizyka Toruń SA, Centrum Badań i Rozwoju Technologii dla Przemysłu SA, Mielec-Diesel Gaz sp. z o.o., Savona Project sp. z o.o., Aspol FV sp. z o.o., Aga-Bauservice sp. z o.o., AMT-Projekt sp. z o.o., Atest-Bud sp.j., Vatra SA, Egoterm sp.j., Przedsiębiorstwo Wielobranżowe JPJ, Globenergia sp. z o.o., Park Naukowo-Technologiczny Euro-Centrum SA and many other companies. 